\title{
Logical Thinking Ability and Expressive Language in Early Childhood Learners
}

\author{
S. Rahayu, Mustaji, B. S. Bachri \\ Universitas Negeri Surabaya \\ Surabaya, Indonesia \\ ayuk.ninh@yahoo.co.id
}

\begin{abstract}
The purposes of this research were to produce a magic box of expressions as a feasible and effective medium in enhancing the ability to think logically and to use expressive language in early childhood. The research used Dick and Carey instructional model. The feasibility was tested using a percentage formula. The effectiveness of this research was tested using a ttest. Finally, the research used one group pre-test post-test design with 30 children as research subjects. The results of this study reveal (1) the development of magic box of expression media for early childhood learners showed an excellent result (2) magic box of expressions is proven effective in improving the skill of children in the sense of thinking logically and in using expressive language. The conclusion is promoting the logical thinking skill and using expressive language in early childhood learners may be done through involving children in a dialog using cause and effect relation.
\end{abstract} Media.

Keywords-component; Childhood; Expressive; Language;

\section{INTRODUCTION}

In 2014, Indonesia officially enacted the 2013 curriculum for Early Childhood Education with the hope that the implementation of this curriculum will provide a solution to human resource crisis in Indonesia. The role of the teacher has shifted from the center of learning to the designer of learning (Britton, 2012). Given the facts, the learning process is designed to encourage children to inquire, to formulate problems through questioning (using expressive language), and to think logically, while at the same time promoting cooperative and collaborative learning in solving problems (Bredekamp,1995).

The ability to think logically and to use expressive language is crucial in children's daily life. As a result, children need to possess the ability to initiate the solutions for their problems, to make a plan for their activities, and to identify cause and effect relation found in their real life (Solso, 2008). The thinking development in early childhood is constructed based on their experiences with the surrounding environment (Jackman, 20012). So that children think not merely based on the prescribed words but from the structure of words in general (Templeten, 2016).

In the process of learning in the classroom, it is important that children have logical thinking ability because naturally, children have shifted from concrete thinking process to abstract thinking process. Thus, language competence becomes vital to support the process. Thinking is a general process to determine an issue in our mind (Davies, 2013). In the case that there are two persons thinking about the same issue, there might be two different outcomes, one is logical and the other one is illogical (Burkey, 2011). This is because logical thinking refers to the correlation in which actions form a relationship in an easy and natural manner (Brown, 2014).

The language competence in children consists of the receptive and expressive ones (Otto, 2015: 3). Receptive language refers to the ability to identify words while expressive language refers to the ability to convey the meaning of words. Using expressive language is the ability to ask questions, to answer questions, to communicate orally, to retell what they have known, to learn pragmatics, to express feeling, ideas, and desires in the form of written transcription (Vigotsky, 2008).

The common problem faced by most early childhood teachers in Indonesia is the limited resource of media that is available to develop logical thinking and expressive language ability. Thus, it is urgent to take actions to develop the suitable media to promote learners' understanding of teacher's instruction (Seefeltdt, 2008).

Learners' interest to the media used in the learning process to achieve learning objectives is very important to create conducive learning atmosphere so that the learning itself can take place efficiently and effectively (Borg, 2003). One of the learning media that can be developed is a quiz game that can test the learners through fun activities (Catron, 1999). However, it is necessary to consider some aspects such as access, cost, technology, interactivity, organization and novelty in determining the suitable learning media. 


\section{METHOD}

This research is a developmental research using Dick and Carey development model (2001) which go through 9 stages. It is aimed at promoting logical thinking ability and using expressive language in early childhood learners at group B of TK ABA Pelangi Tulungagung.

The product is tried out through several stages; instructional material expert validation (2) Instructional design expert validation (3) Instructional media expert validation (4) individual validation (5) small group validation, and (6) field validation. ${ }^{[17]}$ The try-out subject of this research consists of the experts who assist as product validator and the early childhood learners aged 5-6 years old at group B TK Pelangi Tulung Agung. The data collected are (1) data taken from the first stage evaluation in the form of validations from instructional material expert, Instructional design expert, and instructional media expert, (2) the data from individual tryout, small group try out, and (3) data taken from field try-out in the form of pretest and posttest performance in logical thinking ability and expressive language.

The instruments used in this research are the observation form, interview guide, and questionnaires. The data is then analyzed in two corresponding manners (1) descriptivequalitative analysis to analyze data gained from interview and observation in the form of feedback and comments from the try-out subject, and (2) statistic-descriptive analysis to analyze data from questionnaires, and the pretest and posttest scores.

\section{RESULT AND DISCUSSION}

\subsection{Need analysis to identify learning objective}

The lack of logical thinking ability and using expressive language found in the early childhood learners at TK ABA Pelangi Tulung Angunghas becomes the underlying reason why it is very important to conduct the research on promoting logical thinking ability and using expressive language. The learning process in this particular school mainly focuses on grouping model with the secured area, using worksheet and tasks such us rearranging pictures by giving a number in the right column. This task doesn't give the opportunity to learners to know cause and effect relationships and to express it using language accordingly.

\subsection{Conducting Instructional Analysis}

The learning material for logical thinking is; big-small concept, the order of things, miming, game participation, eating and drinking balance, self-care, color, geometry, classification of things, and pattern arrangement.

Material for language expressions is; conversation, personal information, first syllable word similarity, flash card reading, dialog, repeating sentences from listening, expressing ideas and opinions based on a story, completing sentences, and retelling story.

\subsection{Analyzing Learners' Character and Context}

Based on the preliminary identification of observation and the data record, we found out that the learners at Group B TK ABA Pelangi Tulungagung range from 5 to 6 years old of age. In addition, the kindergarten applies Curriculum of 2013 to Early Childhood Education. The learning model used is grouping model with the secured area in which the logical thinking ability and language expressions is not developed yet.

\subsection{Formulating Instructional Objectives}

The learning objectives for logical thinking ability are learners are able to understand: big-small concept, the order of things, miming, game participation, eating and drinking balance, self-care, color, geometry, classification of things, and pattern arrangement.

The learning objectives for using expressive language ability are learners should be able to understand and or perform: conversation, personal information, first syllable word similarity, flash card reading, dialog, repeating sentences from listening, expressing ideas and opinions based on a story, completing sentences, and retelling story.

\subsection{Developing Assessment Instrument}

The development of assessment instrument is aimed at assessing the learners' development in their ability of logical thinking and using language expressions. The assessment is based on the learners' performance with the tasks given referring to the learning objectives in the indicator of logical thinking ability and using expressive language.

\subsection{Developing Instructional Strategy}

The development of instructional strategy in this research focuses mainly on logical thinking ability and using expressive language with regard to learners' character and the compatibility with the curriculum. The learning activity is designed in the form of game activity. The media used may develop all the indicators and cover the materials to promote logical thinking ability and using expressive language. Moreover, the activities are fun and engaging, making students comfortable with the presence of music and colorful lamps.

\subsection{Developing and Selecting Instructional}

The instructional material is in the form of a magic box of expressions media which consist of expression box equipped with music and decorative lamps, 6 types of the card; flash card of 5 senses, the flash card of things, message card, number card, the flash card of geometry, and task card. Those cards are used in the learning activities to promote logical thinking ability and using language expressions in early childhood learners. ${ }^{[16]}$

\subsection{Designing and Conducting Formative Evaluation of} Instruction

In this stage, there were 4 try-outs namely (a)expert validation (b) individual try-out (c) big group try- out, and (d) field try-out. The expert validation comprises the instructional design expert, instructional media expert, instructional material expert, and assessment expert. The individual try-out 
was given to 5 children in group B1, the small group try-out is for 15 children in group B2, and big group try-out is dedicated to 30 children, 15 from B2 and 15 from B3.

The result of t-test showed that $\mathrm{t}$-measure $-5.618>\mathrm{t}$ table -2.045 , so Ho is rejected and $\mathrm{Ha}$ is approved proving that the use of a magic box of expressions media can promote the logical thinking ability dan using expressive language in early childhood learners.

\subsection{Revising Instruction}

The feedback for this magic box of expressions is to use thicker paper for the flash cards and improving the card layout. The cover title of the manual booklet should be added with "logical thinking" and "language expressions". Finally, the researcher team has made the revision and the validators have announced that the manual and the media of magic box of expressions are ready to use and eligible for the examination.

\section{CONCLUSION}

\subsection{Conclusion}

Promoting the logical thinking ability and using expressive language in early childhood learners may be done through involving children in a dialog using cause and effect relation.

\subsection{Acknowledgement}

We would like to express our deepest gratitude to $\mathrm{Mr}$. Munip, S.Pd as the pre-School inspector, Mrs. Dra. Sutini who let the researchers pursue their study, Mr. Marsum, M.Pd who consistently gives encouragement and support, and finally to all teachers at TK ABA Pelangi Tulun-gaging for the continuous assistance.

\section{REFERENCES}

[1] Bredekamp, S., DAP in Early Childhood Programs Serving Children from Birth through Age 8.

[2] Britton, L., 1992. Montessori play \& learn: a parents' guide to purposeful play from two to six. Three Rivers Press.

[3] Brown, C.S., 2014. Language and Literacy Development in the Early Years: Foundational Skills that Support Emergent Readers. Language and Literacy Spectrum, 24, pp.35-49.

[4] Burke, L.A. and Williams, J.M., 2012. Two thinking skills assessment approaches:"Assessment of Pupils' Thinking Skills" and "Individual Thinking Skills Assessments". Thinking Skills and Creativity, 7(1), pp.62-68.

[5] Gall, M.D., Gall, J.P. and Borg, W.R., 2003. Educational research Boston. MA: Allyn and Bacon.

[6] Catron, C.E. and Allen, J., 2007. Early childhood curriculum: A creative play model. Prentice Hall.

[7] Davies, D., Jindal-Snape, D., Collier, C., Digby, R., Hay, P. and Howe, A., 2013. Creative learning environments in education-A systematic literature review. Thinking Skills and Creativity, 8, pp.80-91.

[8] Jackman, H., Beaver, N. and Wyatt, S., 2014. Early education curriculum: A child's connection to the world. Cen-gage Learning.

[9] Johnson, S. and Siegel, H., 2010. Teaching thinking skills. Bloomsbury Publishing.

[10] Otto, B., 2015. Perkembangan bahasa pada anak usia dini. Jakarta: Kencana.

[11] Seefeldt, C. and Wasik, B.A., 2008. Pendidikan anak usia dini: Menyiapkan anak usia tiga, empat, dan lima tahun masuk sekolah. Jakarta: Indeks.

[12] Solso, R.L., Maclin, O.H. and Maclin, M.K., 2008. Psikologi kognitif. Jakarta: Erlangga.

[13] Templeton, S., 2015. Building Foundational and Vocabulary Knowledge in the Common Core, K-8: Developmentally-Grounded Instruction about Words. Language and Literacy Spectrum, 25, pp.7-17.

[14] Vygotsky, L.S., 1986. Thought and language. 1962. Trans. A. Kozulin. Cambridge, MA: MIT P.

[15] Warsono, 2008, Logika Cara Berpikir Sehat, Surabaya, Unesa University Press.

[16] Heinich, R., Molenda, M., Russell, J. D., \& Smaldino, S.E. 2002. Instructional Media and Technology for Learning, 7th Edition. New Jersey: Prentice Hall, Inc.

[17] Dick, W. and Carey, L. 2005, The Systematic Design of Instruction. United States of America, Scott Foresman and Company. 